\title{
Financial Situation Analysis of Entities
}

\section{Banzdai Sainjargal1 ${ }^{1}$ Lombodorj Naranchimeg ${ }^{*}{ }^{(0)}$, Batjargal Khurelbaatar ${ }^{2}$, Choigunsen Chimedsuren ${ }^{3}$}

\author{
${ }^{1}$ Accounting Department, Business School, National University of Mongolia, Ulaanbaatar, Mongolia \\ ${ }^{2}$ Business School, National University of Mongolia, Ulaanbaatar, Mongolia \\ ${ }^{3}$ Accounting Policy Department, Ministry of Finance of Mongolia, Ulaanbaatar, Mongolia \\ Email: ^Inaraa9191@gmail.com
}

How to cite this paper: Sainjargal, B., Naranchimeg, L., Khurelbaatar, B. and Chimedsuren, C. (2020) Financial Situation Analysis of Entities. iBusiness, 12, 1-12. https://doi.org/10.4236/ib.2020.121001

Received: December 11, 2019

Accepted: January 12, 2019

Published: January 15, 2019

Copyright $\odot 2020$ by author(s) and Scientific Research Publishing Inc. This work is licensed under the Creative Commons Attribution International License (CC BY 4.0).

http://creativecommons.org/licenses/by/4.0/

\section{cC (i) Open Access}

\begin{abstract}
The study aims to define the financial situation of Mongolian entities. The objective of research determines the nature of its trend and evaluates the role of accounting and its reporting by reviewing the accuracy and transparency of the reporting information by making analysis including core financial indicators. The data is based on the "Financial statements of the entities" issued by the Accounting policy department, Ministry of Finance of Mongolia and related statistical information. The significance of the study will be more useful to understand a Mongolia's entities' financial nature and make better economic decisions.
\end{abstract}

\section{Keywords}

Entities, Company Assets, Liabilities, Owners' Equity, Financial Characteristics, Proper Structure of Assets Liabilities Plus Owner's Equity

\section{Introduction}

The purpose of the financial analysis is to provide information to financial managers and analysts to make thorough decisions about their business. Assessing financial position and performance of an enterprise is a skill that every manager needs to have to make the best and right decisions for the company [1]. From this concept, financial reporting analysis plays an important role in making decision to provide the resources needed to increase corporate efficiency and in maximizing profitability by increasing production with minimal labor and capital costs. It is imperative to strengthen the Accounting and Reporting role to identify the current financial status and development trends of all entities and thus, it requires to evaluate the accuracy and transparency of the reporting information. 
To ensure accuracy and transparency of reporting it is important to make analysis including core financial indicators. Financial analysis is of special importance to outside stakeholders, because it is based on public financial statements which are the main source of information for outsiders [2]. Our study examines the nature of its trend and evaluates the role of accounting and its reporting by reviewing the accuracy and transparency of the reporting information by making analysis including core financial indicators.

\section{Data and Methodology}

The data of this study consist of financial statements from E-balance data base from the website of Ministry of Finance. An available and reliable data was between 2011 and 2018 to ensure the freshness of the data. The Accounting Law governs accounting in Mongolia. Mongolia has also adopted IFRS. The Accounting Law requires all for-profit and non-profit entities. Related regulations require that electronic filing of financial statements must be within law time and the related financial organization must receive the financial statements and review within 15 workdays.

This research consists a number of qualitative and quantitative analysis. Quantitative analysis uses a ratio analysis including core financial indicators. The ratio analysis is an art of determining relationship between different components of financial statement to derive a significant understanding of liquidity, solvency, profitability and efficiency of entities of Mongolia especially in mining sector. The comparison method was used and the company's financial statements. The analyses construct the current trend, financial conditions of entities and the ratio analysis of the main financial indicators during year of 2013-2018. At last section, we aim to be set the constraints to determine the target balance to meet the minimum level of financial indexes for mining companies. Mathematical methods were used to determine the optimal structure of capital sources. It focuses to the target balance sheet to keep it at a minimum optimal structure. There are mathematical constraints to determine the target balance to meet the minimum level of financial indexes for mining companies using methodology of research of Naranchimeg L ${ }^{1}$ [3].

$$
\begin{gathered}
\min \left(\delta_{1} x_{1}+\delta_{2} x_{2}\right) \\
x_{1}+x_{2} \geq 2 \mathrm{STL}-\mathrm{CA} \\
x_{1}+x_{2} \leq \mathrm{TA}-2 \mathrm{CA} \\
x_{2} \leq \mathrm{TA}-\mathrm{OE} \\
0.1 x_{1} \leq \mathrm{NI}-0.1 \mathrm{OE} \\
x_{1}-x_{2} \leq 10 \mathrm{NI}-\mathrm{TA} \\
x_{1}+x_{2} \geq 2 \mathrm{TL}-\mathrm{TA}
\end{gathered}
$$

Significance to offer these arguments, it effects company independent activity

${ }^{1}$ L. Naranchimeg, 2011, Theory and Methodology of Financial Stability Analysis, Shinro print LLC, Ulaanbaatar. pp. 2011-2120. 
and the financial stability. The research problem is to find a systematic way to solve on obtaining, collecting and analysis of data with different formats of financial information data seen on the system.

\section{Analyses}

\subsection{Current Structure of Consolidation Data of Financial Statements}

The Accounting Law governs accounting in Mongolia. Mongolia has also adopted IFRS. The Accounting Law requires all for-profit and non-profit entities, including small and medium enterprises (SME), state-owned enterprises (SOE), and other entities to prepare financial statements in full compliance with IFRS. Related regulations require that electronic filing of financial statements must be within law time (The clause No.9.1 of Accounting Law) and the related financial organization must receive the financial statements and review within 15 workdays (The clause 3.1, Order No. 243/2017 by Ministry of Finance).

This section determines the current E-balance system ${ }^{2}$ introduced by the Ministry of Finance, Mongolia to consolidation data base of financial statements for all entities. E-balance system for allowing electronic filing and submission of financial statements by firms with more than 60,000 entities was upgraded and implemented in Mongolia by 2013. The system, used to be accepted for the only one form of reporting, has revised to be submitted by 7 types of entities (including entities, non-governmental organizations, securities institutions, banks, insurance companies, non-bank financial institutions, savings and credit cooperatives) and the data entries give the possibility to enter manual financial statements, computer files and, import information. Furthermore, the database enables to consolidate and analyze for the financial statements by each sector, business and ownership types. It is also possible to exchange information with the Ministry of Finance and other government agencies, and currently, based on more than 40 requests, including the Bank of Mongolia, the National Statistical Office, the State Property Committee, Mongolian State University of Agriculture, National Police Agency and the General Department of Taxation have been granted the right to receive data of financial statements.

Table 1 shows numbers of firms registered on the "E-balance" database. The data exhibits about 100,000 entities in 2018, which is $40 \%$ more than in 2011. There is different growth in each industry. Entities including non-governmental organizations, companies, non-banking financial institutions and savings cooperatives have grown every year. Non-governmental organizations are expected to grow as the role of non-governmental organizations has increased in recent years. Brokerage company has declined to the weak development of the Mongolian stock market.

The below Figure 1 and Figure 2 present the total assets and sales revenue by total firms.

${ }^{2}$ E-balance system, Introduced by Ministry of Finance, Mongolia, Link:

https://e-balance.mof.gov.mn 


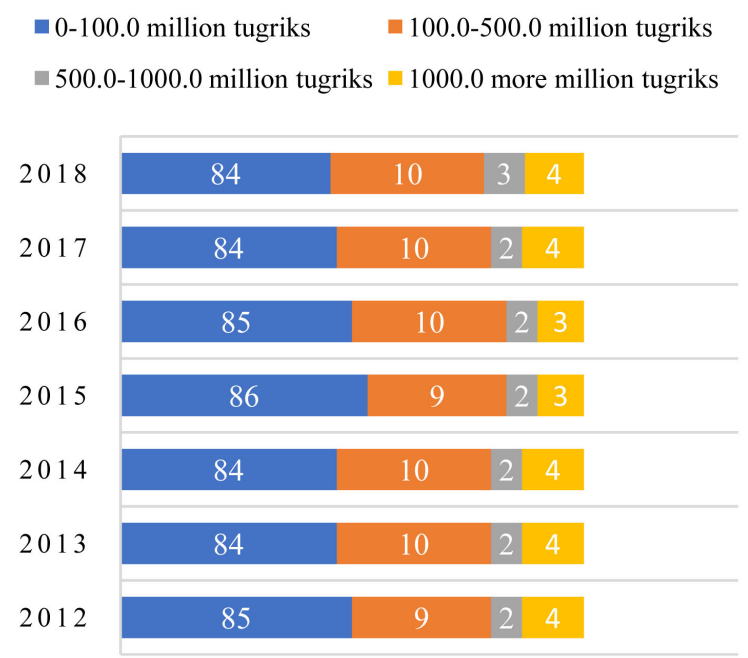

Figure 1. Sales revenue by firms (by percentage).

$$
\begin{aligned}
& \square-100.0 \text { million tugriks } \quad \square 100.0-500.0 \text { million tugriks } \\
& \square \text { 500.0-1000.0 million tugriks } \square 1000.0 \text { more million tugriks }
\end{aligned}
$$

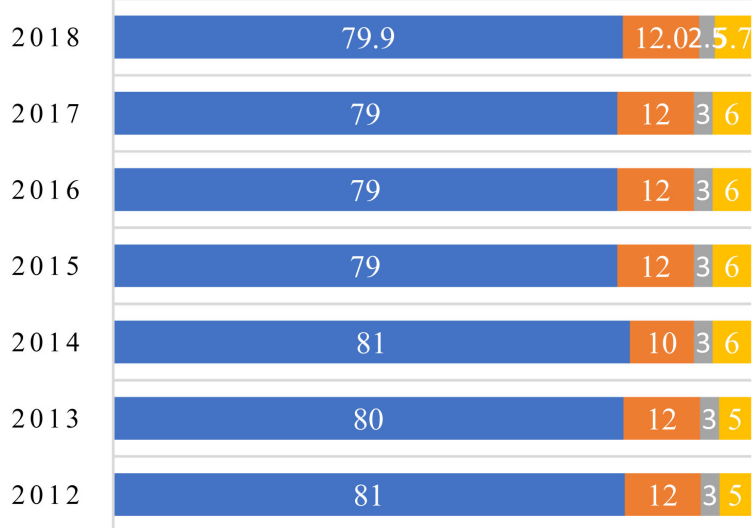

Figure 2. Total assets by firms (by percentage).

\begin{tabular}{|c|c|c|c|c|c|c|c|c|c|}
\hline Year & LLC & Other & NGO & NBFI & MSE & SCC & Bank & Insurance & Amount \\
\hline 2011 & & 52,510 & 3183 & & & 233 & & & 60,198 \\
\hline 2012 & & 58,449 & 3909 & & & 192 & & & 67,381 \\
\hline 2013 & & 66,767 & 4111 & 270 & 77 & 120 & 17 & 13 & 71,375 \\
\hline 2014 & & 72,859 & 5579 & 348 & 67 & 190 & 18 & 14 & 79,075 \\
\hline 2015 & & 77,508 & 6447 & 390 & 67 & 215 & 17 & 14 & 84,658 \\
\hline 2016 & & 79,058 & 6759 & 430 & 48 & 226 & 17 & 16 & 86,564 \\
\hline 2017 & & 81,091 & 7319 & 459 & 55 & 247 & 16 & 17 & 89,204 \\
\hline 2018 & & 90,164 & 9845 & 471 & 55 & 278 & 14 & 14 & 100,841 \\
\hline
\end{tabular}

Table 1. Number of firms E-balance database.

Source: The consolidation of the financial statements by firms, years 2007-2018. LLC: Limited Liability Company; PC: Public company; NBFI: Non-Bank Financial Institutions; MSE: Mongol Securities Exchange; SCC: Savings and Credit Cooperatives. 
According to the above figures, the number of firms reached to MNT 500.0 million for total assets and up to MNT 1.5 million for sales revenue accounts for $91 \%$ to $94 \%$ of total firms. But these firms occupy only 2 - 3 percent of total assets and 10 percent of sales revenues of all firms. However large enterprises occupy $14 \%$ to $21 \%$ of all firms, they represent $98 \%$ of the total assets and $90 \%$ of their sales revenue and, their participation in the market has increased for the last 6 years.

The survey shows increasing number of entities reporting submitting their reports on the E-Balance Sheet Financial Reporting System year by year (Figure 1). The result presents $84 \%$ of all entities that have sales revenue of MNT $0-100.0$ million. It means that the most of entities in Mongolia are small sized firms in Mongolia.

\subsection{Survey on Financial Conditions of Entities}

The average mean in the data (Table 2) of last 6 years shows that current assets are $57.3 \%$, non-current assets are $42.7 \%$ of total assets and, the proportion of current assets is declining in recent years (2013-2017), thus, affecting negatively to asset liquidity and asset turnover.

Total assets have increased by $88.5 \%$ or from MNT 78,254 to MNT 147,254 billion since 2013 and by $1 \%$ or MNT 1808.0 billion in 2018 .

However, the significant growth has been done for years of 2012 to 2013 and the growth rate stabilized in the next year and, because of the average increase in the non-current assets in 2017 increased by 1.5 times compared to the previous year, by accumulating average mean of total assets for years of 2013-2018. It shows that current assets occupy $57.2 \%$ and $42.8 \%$ non-current assets of total assets.

Table 2. The structure of assets, liabilities and owners' equity (by percentage).

\begin{tabular}{|c|c|c|c|c|c|c|c|}
\hline \multirow[b]{2}{*}{ Accounts } & \multirow[b]{2}{*}{2014} & \multirow[b]{2}{*}{2015} & \multirow[b]{2}{*}{2016} & \multirow[b]{2}{*}{2017} & \multirow[b]{2}{*}{2018} & \multicolumn{2}{|c|}{ Average between $2013-2018$} \\
\hline & & & & & & Percentage & $\begin{array}{c}\text { Growth } \\
\text { percentage }\end{array}$ \\
\hline \multicolumn{8}{|l|}{ Asset } \\
\hline Current asset & 63.4 & 50.9 & 61.5 & 53.9 & 55.5 & 57.3 & 112.25 \\
\hline Non-current asset & 36.6 & 49.1 & 38.5 & 46.1 & $44, .5$ & 42.7 & 120.25 \\
\hline Total assets & 100.0 & 100.0 & 100.0 & 100.0 & 100.0 & 100.0 & 115.41 \\
\hline \multicolumn{8}{|l|}{ liabilities and } \\
\hline \multicolumn{8}{|l|}{ Owners' equity } \\
\hline Short term liabilities & 57.3 & 54.0 & 50.5 & 44.1 & 43.7 & 50.0 & 109.16 \\
\hline Long term liabilities & 20.5 & 19.0 & 22.9 & 15.8 & 16.7 & 18.8 & 110.64 \\
\hline Total liabilities & 77.80 & 73.0 & 73.4 & 59.9 & 60.4 & 68.8 & 109.56 \\
\hline Owners' equity & 21.20 & 27.0 & 26.6 & 40.1 & 39.6 & 31.2 & 130.22 \\
\hline $\begin{array}{l}\text { Total liabilities and } \\
\text { Owners' equity }\end{array}$ & 100.0 & 100.0 & 100.0 & 100.0 & 100.0 & 100.0 & 115.41 \\
\hline
\end{tabular}

Source: The consolidation of the financial statements by firms, years 2007-2018. 
Total assets are divided into $60.4 \%$ for liabilities and $39.6 \%$ for equity respectively by 2018 and owner's equity has been increased for the last 3 years. The short-term liabilities exhibit 50\% and are long-term liabilities exhibit $18.8 \%$ of the total liabilities of the business entities.

Table 3 exhibits that the result of balance sheet that the variable current assets are provided by the short-term liabilities and $41 \%$ of the fixed current assets is occupied by the owner's equity in 2016 , then the financing is decreased by $24.3 \%$ in 2017 and 24.5 percent in 2018 respectively.

The non-current assets are financed by long-term loans, liabilities and owner's equity which occupied $24.3 \%-75.7 \%$.

About two thirds (69.2\%) (Table 4) of the increase of the total assets is referred to the rise in liabilities (especially $72.9 \%$ by short-term liabilities) in case of the average mean between 2013 and 2018. 30.8\% as the remaining total assets is provided with a growth for owner's equity. However, the percentage of debt occupied in total financing has declined, indicating an improvement in financial independence of companies (especially between 2014 and 2015). By the end of 2018, a non-current asset which shows $45.2 \%$ of the total assets and liabilities which shows $61.6 \%$ of the total assets respectively, but the proportion of owner's equity has declined significantly compared with the previous year. A not more portion of owner's equity due to the lack of financing of long-term liabilities are used for financing for non-current assets. It also should not take into consideration that negatively affects the supply of current assets.

In the last 6 years, $3 / 4$ or $69.2 \%$ and $30.8 \%$ of the total assets were financed by the long and short-term debt and, owner's equity respectively, and the growth for the owner's equity was increased by 2017.

Table 3. Matrix balance sheet (billion, MNT).

\begin{tabular}{cccccc}
\hline Accounts & OH & $\begin{array}{c}\text { Variable } \\
\text { current } \\
\text { assets }\end{array}$ & $\begin{array}{c}\text { Fixed } \\
\text { non-current } \\
\text { assets }\end{array}$ & $\begin{array}{c}\text { Non-current } \\
\text { assets }\end{array}$ & $\begin{array}{c}\text { Balance } \\
\text { sheet }\end{array}$ \\
\hline Short-term liabilities & 2016 & 56,909 & & & 56,909 \\
& 2017 & 64,272 & & & 64,272 \\
& 2018 & 70,011 & & 25,795 & 25,795 \\
\hline \multirow{2}{*}{ long-term liabilities } & 2016 & & & 22,991 & 22,991 \\
& 2017 & & & 26756 & 26,756 \\
\hline Owner's equity & 2018 & & 12,379 & 17,547 & 29,926 \\
& 2016 & & 14,241 & 44,241 & 58,482 \\
& 2017 & & 18,880 & 44,432 & 63,312 \\
\hline Balance sheet & 2018 & & 12,379 & 43,342 & 112,630 \\
& 2017 & 64,272 & 14,241 & 67,232 & 145,745 \\
& 2018 & 70,011 & 18,880 & 71,188 & 160,079 \\
\hline
\end{tabular}


Besides defining the percentage of business activity and its growth direction of any business entity to the quantities produced, products or services produced and the percentage of their income, it is desirable to determine the dynamic analysis of the growth of key economic indicators in a particular order [3]. The researchers emphasized that the growth ratio of the assets financing structure, its growth rate or the growth normative ratio of the basic parameters, would have relationships like that are $\mathrm{OE}>\mathrm{NCA}>\mathrm{TA}>\mathrm{CA}>\mathrm{TL}$ [4]. However the normative of the growth ratio is referred to the dependence of the financial stability, it would be differed in case of the yield for capital the invested. In comparison with the growth ratio, it would be possible if the not only for the current year but also for the average growth over the last 3 to 5 years [5] (Table 5).

Totally, the information data covering the amount number of entities covered by the financial statements was consolidated for firms shows that profit and sales are 56,582.0 billion MNT and earned 2377 billion MNT (7.58 dollars per income). The sales revenue was comparable to the total cost of the sales sold, the sales and general management (operating costs) structure of the company as a whole company.

Table 4. Assets and its funding sources.

\begin{tabular}{cccc}
\hline Year & Liabilities and Owner's equity & Percentage & Assets \\
\hline 2016 & Short-term liabilities & 100 & Variable current assets \\
2017 & Short-term liabilities & 100 & Variable current assets \\
2018 & Short-term liabilities & 100 & Variable current assets \\
2016 & Long-term liabilities & 100 & Non-current assets \\
2017 & Long-term liabilities & 100 & Non-current assets \\
2018 & Long-term liabilities & 100 & Non-current assets \\
2016 & Owner's equity & 41.0 & Fixed non-current assets \\
& Owner's equity & 59.0 & Non-current assets \\
2017 & Owner's equity & 24.3 & Fixed non-current assets \\
& Owner's equity & 75.7 & Non-current assets \\
& Owner's equity & 29.8 & Fixed non-current assets \\
& Owner's equity & 71.2 & Non-current assets \\
\hline
\end{tabular}

Table 5. The growth of core indicators for firms.

\begin{tabular}{|c|c|c|c|c|c|c|}
\hline \multicolumn{2}{|c|}{ Indicators } & $\begin{array}{l}\text { Owner's } \\
\text { equity }\end{array}$ & $\begin{array}{c}\text { Non-current } \\
\text { assets }\end{array}$ & $\begin{array}{l}\text { Total } \\
\text { assets }\end{array}$ & $\begin{array}{l}\text { Current } \\
\text { assets }\end{array}$ & $\begin{array}{c}\text { Total } \\
\text { liabilities }\end{array}$ \\
\hline \multicolumn{2}{|c|}{ Normative ratings $(\mathrm{R})$} & 1 & 2 & 3 & 4 & 5 \\
\hline \multirow{2}{*}{$\begin{array}{l}\text { The report as } \\
\text { consolidated }\end{array}$} & $\begin{array}{c}\text { Increase or } \\
\text { decrease } \\
\text { in } 2018\end{array}$ & $108.5(4)$ & $106.1(5)$ & $109.93(3)$ & $113.2(1)$ & $110.89(2)$ \\
\hline & $\begin{array}{l}\text { The average } \\
\text { growth for } \\
\text { last year }\end{array}$ & $130.22(1)$ & $120.2(2)$ & $115.41(3)$ & $112.2(4)$ & $109.5(5)$ \\
\hline
\end{tabular}




\subsection{Survey of Financial Indicators of Entities}

According to consolidated data for financial statements it is reported of MNT 56,582 billion for the sales and MNT 2,377 billion (MNT 7.58 per sales) interest incomes.

We analyzed a structure of the total cost of the sales sold referred to the sales revenue and the sales and general management (operating costs) costs for as a whole firms (Table 6 and Table 7).

Independence coefficient defines a percentage of equity in total assets and it is preferable that the theoretical value is less than $60 \%$ for that ratio [6]. Companies' independence coefficients and the own financing tend to increase coming years, resulting $21 \%$ to $40.1 \%$ especially the last six years, and the dependence of external sources has decreased from $79 \%$ to $60.9 \%$.

A regulation coefficient exhibits the current capital to equity ratio [7] [8]. This ratio shows the results of $26.9 \%-27.8 \%$ in $2013-2014$ and it was sharply reduced due to short-term debt growth in 2015. This means that a financial situation of enterprises is getting deterioration and a dependent on years having loan. However, resulting of the growth for the ratio during years of 2016-2018, the equity

Table 6. Total revenues and its structure.

\begin{tabular}{|c|c|c|c|c|c|c|c|c|}
\hline \multirow{2}{*}{ Indicators } & \multicolumn{6}{|c|}{ Percentage } & \multicolumn{2}{|c|}{$\begin{array}{c}\text { Average between } \\
\text { 2013-2018 }\end{array}$} \\
\hline & 2013 & 2014 & 2015 & 2016 & 2017 & 2018 & Percentage & $\begin{array}{c}\text { Annual } \\
\text { growth (\%) }\end{array}$ \\
\hline $\begin{array}{l}\text { 1) Sales revenue and } \\
\text { interest income }\end{array}$ & 100 & 100 & 100 & 100 & 100 & 100 & 100.00 & 111.8 \\
\hline 2) Cost of the sales sold & 73.7 & 74.0 & 72.8 & 74.9 & 71.8 & 71.3 & 72.89 & 111.0 \\
\hline $\begin{array}{l}\text { 3) Sales and general } \\
\text { management } \\
\text { (operating costs) costs }\end{array}$ & 20.1 & 22.3 & 23.7 & 28.7 & 25.8 & 18.2 & 23.02 & 109.6 \\
\hline $\begin{array}{l}\text { 4)Operating revenue } \\
\text { (loss) }\end{array}$ & 6.2 & 3.7 & 3.5 & -3.7 & 2.7 & 10.5 & 4.09 & 124.2 \\
\hline $\begin{array}{l}\text { 5) Income before tax } \\
\text { (loss) }\end{array}$ & 1.1 & 1.8 & 1.0 & -5.7 & 7.6 & 6.4 & 2.70 & 159.5 \\
\hline $\begin{array}{l}\text { 6) Income After Tax } \\
\text { (loss) }\end{array}$ & $(1.3)$ & $(0.9)$ & $(3.2)$ & -6.0 & 5.5 & 4.2 & 0.47 & - \\
\hline
\end{tabular}

Table 7. Key financial indicators.

\begin{tabular}{lccccccc}
\hline \multicolumn{1}{c}{ Indicators } & $\mathbf{2 0 1 3}$ & $\mathbf{2 0 1 4}$ & $\mathbf{2 0 1 5}$ & $\mathbf{2 0 1 6}$ & $\mathbf{2 0 1 7}$ & $\mathbf{2 0 1 8}$ & 6-year average \\
\hline 1) Independence coefficient & 21.6 & 22.2 & 26.7 & 26.5 & 40.1 & 38.4 & 30.8 \\
2) Regulation coefficient & 27.8 & 27.1 & -12.9 & 41.3 & 24.4 & 24.5 & 21.7 \\
3) Payable turnover & 3.62 & 3.51 & 2.74 & 2.76 & 1.49 & 1.6 & 2.2 \\
4) Current assets turnover & 1.1 & 1.1 & 0.94 & 1.22 & 1.22 & 1.21 & 1.1 \\
5) Asset turnover ratio/\% & 2.55 & 1.4 & 1.04 & -1.26 & 0.87 & 0.36 & 0.5 \\
6) Equity turnover ratio/\% & 2.08 & 3.13 & 1.05 & -1.97 & 6.96 & 4.13 & 0.5 \\
\hline
\end{tabular}


ratio to current assets financing reached $21.7 \%$ over average of 5 years. The debt-to-debt ratio is likely to decline due to the small increase in the equity ratio.

The current ratio measures whether or not your business has enough resources to pay its bills over the short time [9] [8]. This ratio is 0.94 to 1.2 , which is almost twice lower than the required amount, indicating insufficient liquidity.

The ratio as net profit relative to its total net assets is considered to be an indicator of how effectively a company is using its assets to generate earnings [8] [10].

The average mean of return on investment for 6 years is $0.5 \%$ of the total assets and $0.5 \%$ of the equity respectively, which has been decreasing consecutively; moreover it shows a negative return in 2015 and 2016.

At conclusion, our research suggests that there are needs to be strengthened financial independence in way of increasing the current assets financing, reducing the interest rate and the tax burden, and increasing its equity remaining by distributing income for stock companies and LLC occupying more than $80 \%$ of the total income of a whole entities to overcome the financial crisis.

\subsection{Asset and Its Financing Structure (Main Industries)}

We made the analysis of the main financial indicators including the ratio of current assets, return on invested capital, the regulation coefficient and the independence coefficient in the previous section. These results present lower values than the appropriate level for indicators. Thus, there is a need to determine the target balance to meet the minimum level of financial indexes for mining companies.

The objective of the "State Minerals Policy" is to establish stable investment environment, to improve quality of mineral exploration, mining and processing by encouraging use of environment friendly and advanced techniques, technologies and innovations, to produce value-added final products and strengthening competitiveness of the country in the international market [11].

Our study of current financial situation of Mongolian mining companies shows that increasing role of the mining sector in the Mongolian economy has a positive impact on economic growth. However, the study shows the result of unstable financial conditions, higher ratio of debt to equity and not enough yield of assets for the mining sector. We aim to be set the following constraints to determine the target balance to meet the minimum level of financial indexes for mining companies [12] [13].

$$
\begin{gathered}
\min \left(\delta_{1} x_{1}+\delta_{2} x_{2}\right) \\
x_{1}+x_{2} \geq 2 \mathrm{STL}-\mathrm{CA} \\
x_{1}+x_{2} \leq \mathrm{TA}-2 \mathrm{CA} \\
x_{2} \leq \mathrm{TA}-\mathrm{OE} \\
0.1 x_{1} \leq \mathrm{NI}-0.1 \mathrm{OE} \\
x_{1}-x_{2} \leq 10 \mathrm{NI}-\mathrm{TA} \\
x_{1}+x_{2} \geq 2 \mathrm{TL}-\mathrm{TA}
\end{gathered}
$$


STL: short-term liability, CA: current assets, TA: total assets, OE: owner's equity, NI: net income, TL: total liability.

According to the study, to meet the target balance (structure) we offer, the mining sector and representative companies need to have followings:

1) A balance of current assets should be increased by at least $80 \%$;

2) Reducing short-term financing by $47 \%$;

3) Increase 1.6 times the owner's equity by increasing retained earnings and issuing shares.

Condition 1: Calculate the optimal balance sheet structure in average means for 19 companies selected in the mining sector to keep the amount of $\delta_{1} x_{1}+\delta_{2} x_{2}$ up to the minimum;

Condition 2: Reach to at the normative level or 2:1 for the average turnover ratio of the mining sector is $1: 1$ and the average mean of the 19 companies selected is 0.5 ;

Condition 3 and 4: For the mining sector, the independence coefficient 0.12 , the average mean of the 19 companies surveyed is 0.1 , should be no less than 0.5 or more than 1;

Condition 5: Average mean of a return on equity for the industry companies and for 19 companies is 0.1 , should be no less than 0.1 ;

Condition 6: Increase the total return on the industry by sector $(0.01)$, to 5 percent;

Condition 7: The proportion of external capital is $88 \%$, should be no more than $50 \%$.

In a result of implementing these arguments, mining companies will be able to work independently, and will be possible to create a new balance sheet structure to meet the financial stability, asset utilization, and the lowest return on total assets and equity.

The result of our analysis shows that there is a need to increase working capital by $80 \%$, reduce short-term loans by $47 \%$ and increase equity by 1.6 times in order to meet the minimum level of financial basic indicator in sector of mining companies.

\section{Conclusions}

The financial condition of entities that national wealth is created in a scope of the entity including initial financial distribution is the basis of economic stability. However, most companies are small for their size and large enterprises occupy about $14 \%$ to $21 \%$, large enterprises occupy over $80 \%$ of the total revenues.

Our results show that there is a tendency to have decrease for financial dependence and increase in the effectiveness of its activities in the comparative data of 2018 and the last 6 years, but the industry sustainability principles can't be implemented. In recent years, debt-to-equity ratio has been declining, however, the financing of current assets is inadequate, and companies shifting to classification of $\mathrm{B}$ or $\mathrm{C}$ in a result that the return on equity has been reduced annually. 
The higher level of small-sized entities occupied in entities may be effect on their proper structure which has not yet been formed but also, their poor effect on economic growth and their financial vulnerability. The fact that entities have financed over $50 \%$ of their equity through short-term loans and insufficient availability long-term financing. Their financing mostly converts into their noncurrent assets or this causes a poor liquidity to the entities. It concludes that entities will be good if they make regularly analyze their financial statements, manage their assets properly, and possible to maintain a proper balance management for meeting the target level of main financial indicators [14] [15] [16].

We suggest that it will be more supportable in defining sector policies by creating cumulative data series of financial circumstances of firms, providing transparency information of the reporting and improving the usefulness of the data for research, moreover, analyzing and evaluating the factors affecting the financial difficulties by the size, ownership in a result of improving the consolidation of the financial statements of Mongolian entities.

Our study is limited for industry. This study only considers mining companies. Moreover, an attention should be paid to the behavior of financial ratios in different industries.

\section{Conflicts of Interest}

The authors declare no conflicts of interest regarding the publication of this paper.

\section{References}

[1] Hasanaj, P. and Kuqi, B. (2019) Analysis of Financial Statements: The Importance of Financial Indicators in Enterprise. Humanities and Social Science Research, 2, 17-27. https://doi.org/10.30560/hssr.v2n2p17

[2] Laitinen, E.K. (2018) Financial Reporting: Long-Term Change of Financial Ratios. American Journal of Industrial and Business Management, 8, 1893-1927. https://doi.org/10.4236/ajibm.2018.89128

[3] Naranchimeg, L. (2011) Theory and Methodology of Financial Stability Analysis. Shinro Print LLC, Ulaanbaatar, 120.

[4] Accounting Policy Department, Ministry of Finance of Mongolia. Consolidation data of Financial Statements for Entities 2013-2018.

[5] Statistical Bulletin of Mongolia, 2007-2018. Ulaanbaatar.

[6] Sainjargal, B. (2009) Financial Statement Analysis. Ulaanbaatar, 424.

[7] Савицкая, Г.В. (2016) Методика комплексного анализа хозяйственной деятельности. Изд-во Проспект, Москва.

[8] State Policy on the Mineral Sector, Years of 2013-2024.

[9] Ariunbold, U. and Naranchimeg, L. (2019) Financial Analysis for Mining Companies. Business Innovation.

[10] Валерьевич, И.В. (2007) Оценка эконимической устойчивости промышленного предприятия, Москва, 65.

[11] Molomjamts, D. (2017) Financial Analysis. Ulaanbaatar, 8. 
[12] Гиляровская, Л.Т., Лысенко, Д.В. and Ендовицкий, Д.А. (2008) Комплексный экономический анализ хозяйственной деятельности, Москваон, 257.

[13] Erkhesh, A. (2016) Present Performance Measurement Practice of Mongolian Companies. The Business Education Journal, No. 27, 73-74.

[14] Enkhbat, R. (2006) Optimization-2 (Calculus of Variations with Economic Applications). NUM Press, Ulaanbaatar.

[15] Robinson, T.R., Henry, E., Pirie, W.L. and Broihahn, M.A. (2012) International Financial Statement Analysis. CFA, 503-510.

[16] Tungalag, N., Erdenebat, M. and Enkhbat, R. (2017) A Note on Economic Order Quantity Model. iBusiness, 9, 74-79. https://doi.org/10.4236/ib.2017.94006 